\title{
The microbiological detection of Mycobacterium tuberculosis from oral lesion
}

\author{
Atik Kurniawati \\ Department of Oral Biology \\ Faculty of Dentistry Jember University \\ Jember - Indonesia
}

\begin{abstract}
Tuberculosis is a chronic infectious disease caused by Mycobacterium tuberculosis. The oral manifestations of tuberculosis have been reported. The objectives of this study was to detect Mycobacterium tuberculosis from oral lesions by swabbing. Samples were received from collected primary data on annually clinical report status and then clinical intra oral examination was performed. Oral lesions were swabbed and cultured using Lowenstein Jensen media, Middlebrook 7 H9 and Middlebrook 7H10. Positive culture were recorded and observed everyday until 8 weeks. From 66 samples, there were 2 patients with ulcer as an oral clinical manifestation with location on the tongue. Culture examination revealed 2 positive samples. It was inferred that Mycobacterium tuberculosis could be detected in oral lesion by swabbing.
\end{abstract}

Key words: microbiological detection, M. tuberculosis, oral lesion

Correspondence: Atik Kurniawati, c/o: Bagian Biologi Oral, Fakultas Kedokteran Gigi Jember. Jln. Kalimantan no. 37 Jember 68121, Indonesia. E-mail: atikku_fkgunej@yahoo.com

\section{INTRODUCTION}

Tuberculosis is a chronic infectious granulomatous disease caused by Mycobacterium tuberculosis, less frequently by Mycobacterium bovis or by other atypical mycobacteria. Depending on the portal of entry of infection and on the degree of haematogenous many organs and system of the body could be affected. The common site of infection is the lungs. ${ }^{1}$

Tuberculosis is a disease of global importance. One third of the world population is estimated to have infection with Mycobacterium tuberculosis and eight million new cases tuberculosis arise each year. The tuberculosis crisis is likely to escalate since the human immunodeficiency virus (HIV) epidemic, as a result greater increased in the number of tuberculosis cases. The majority of tuberculosis patients are 15 to 45 years of age, mostly in productive years of live. Tuberculosis kills over two million people world wide each year, more than any single infectious disease, including AIDS and malaria., ${ }^{2,3}$

In Indonesia, new cases of this disease exceed 150 000 per year or 8 per 10000 persons and those with latent infection are estimated 24 per 10000 persons, based on Survei of Kesehatan Rumah Tangga (SKRT 1996). Tuberculosis in Indonesia was the third current incidence in the world after The Republic of China and India. ${ }^{4}$

Primary infection of tuberculosis in human ussually occurs in the lungs and consist of a localized lesion at the site of impaction of the bacilli and, at a later stage, regional adenitis. Initially, litlle or no tissues reaction take place but after a period of weeks or months delayed hipersensitivity to the tubercle bacillus develope and the host tissues react with an intense inflammatory response with caseations. The lesion may heal by fibrosis and calcification, or an equilibrium between the host and tubercle bacilli may develope, which, if disrupted, produce symptomatic disease many years later. The lesion may progress, spreading locally in the lungs and eroding in to bronchi, producing open tuberculosis, or in the bloodstream, to produce a disseminated form of the disease, including in oral cavity. $3,5,6,7$

The oral manifestations of tuberculosis have been reported. ${ }^{7,8,9,10}$ Oral lesions were usually secondary to primary tuberculosis infection elsewhere in the body. Primary infections of the oral mucosa by Mycobacterium tuberculosis have been described even they are rare. The source of infection is infected sputum or blood-borne bacilli in the case of secondary infection, while in primary infection the source is unknown. Lesions are found more commonly in the posterior parts of the mouth and it has been suggested that there is related to the relative distribution of lymphoid tissue. There is wide variation in the clinical presentation of tuberculosis lesions of the oral mucosa, with ulceration and pain being commonly reported. However, diffuse inflammatory lesions, granulomas and fissures have also been described and pain may be mild or absent. The tongue is probably most commonly affected, but lesions have been noted on the buccal mucosa, gingival, floor of mouth, lips and the hard and soft palate as well. ${ }^{8,9,10,11}$

Pulmonary tuberculosis is suggested by persistent productive cough for three weeks or longer, weight loss, night sweats and chest pain. Pulmonary tuberculosis usually occurs in the apex of the lungs. These developed cavities which contain large population of tubercle bacilli can be 
detected in a sputum specimen. The diagnosis can only be made reliable on demonstrating the presence of tubercle bacilli or Acid Fast Bacilli (AFB) the sputum by means of microscopy and/or culture in the laboratory. ${ }^{1,2,13,14}$ But not all patients that have been diagnosed suspect tuberculosis pulmonary, the sputum could not enough be turned out with coughing when examined, so the AFB test was negative and diagnosed as non tuberculosis, whereas they potentially for spreading tuberculosis disease. Therefore, in this research, the method of taking samples by swabbing within oral lesion, used one of alternative sampling method to diagnosed tuberculosis disease.

The purpose of the research was to detect Mycobacterium tuberculosis from oral lesion by culture.

\section{MATERIAL AND METHOD}

The research was a laboratory observation, conducted on the population of lung tuberculosis with criteria: the patients were diagnosed as tuberculosis based on the Lung Tuberculosis Guidance stated by Health Department of Republic of Indonesia, ${ }^{4}$ productive-aged (15-60 years old), carrying no other systemic diseases, male or female, new tuberculosis patients (initially diagnosed) with positive AFB, or they who were still in curing process.

The material, purchased from the specimens were lesions taken from the oral cavity of lung tuberculosis patients. Oral lesion is a scar resulting in damage and inflammation on oral mucosa. Conducting swab with particular swab instrument. Swab was a process of wiping on the mucosa of the lesion after the exudates was previously cleaned..$^{5}$ The result of swabbing subsequently stored directly into liquid media Middlebrook 7H9 as the carrier. The growth shape of bacteria within the liquid media was marked by the presence of muddiness. The specimen should be delivered to laboratory soon for further procedure of decontamination. The decontamination was conducted in respect with the recommendation of WHO using sodium hydroxide method. This method provide very effective result, foremost, if fulfilling some factors such as limitation of decontamination time (15 minutes), centrifugation upon the speed of $3500 \mathrm{rpm}$ because it was possible a lot of bacteria contained in the swab result, rinsing using PZ sterile to reduce or remove further effect of bactericidal sodium hydroxide that only optimally eradicated other bacteria except $M$. tuberculosis. After the swabbing result had been centrifuged, the supernatant was disposed into lisol. The sediment and the media remnant were respectfully suspended by vortaking. The result of this suspension was wholly cultured and planted in the solid media in order to be askew Lowenstein Jensen (L.J Media) and Middlebrook 7H10. The culture was stated positive if it had been Mycobacterium tuberculosis, exhibiting rough colony, white cream-coloured, broccoli like- flowershaped on the Lowenstein-Jensen media and rough colony formation, dry, scaling, yellowish cream-coloured on the surface of culture media on the Middlebrook $7 \mathrm{H} 10 .{ }^{13,14,15}$

\section{RESULT}

The research observed 66 tuberculosis patients, and oral examination was conducted. It was found that 2 patients had oral lesions, or as much as $3 \%$. The lesions were ulcers on the tongue. Both lesions were subsequently swabbed, and the result showed that there was positive culture growth.

\section{DISCUSSION}

The accuracy of detection M. tuberculosis from swabbing oral lesions of tuberculosis patients was influenced by the factor of swabbing, delivering, maintaining or the process of decontamination concentration as well as the examining method of microbiological laboratory. ${ }^{16}$

Swabbing from oral lesion was conducted using sterile swab by pressing and spinning swab on the lesion surface and putting it in the liquid media of Middlebrook 7H9. It was liquid media as the carrier of specimen so it was not dry and dead regarding the result which was frequently very little so it needed maintaining the life circumstance as in the lesion environment. Besides, it helped the growth of M. tuberculosis since this media was abundant in nutrition so that improved the detecting sensitivity toward $M$. tuberculosis in the specimen.

In this research, growing media was conducted through duplo using Lowestein-Jensen media and Middlebrook 7H10 that was aimed at increasing the detecting sensitivity toward M. tuberculosis, increasing the detecting performance of $M$. tuberculosis in small number from 1 up to 100 micro-bacteria such as in the swab or sputum of the patients that were still in the curing treatment. Thus, this research improved the detecting sensitivity toward M. tuberculosis in the lesion swabbing specimens with a method using liquid media for the culture and transportation, and was subsequently followed by culture in the two solid media (duplo) of Lowenstein-Jesen (L-J) and Middlebrook 7H10. After the swabbing result had been centrifuged, the supernatant was disposed into lisol. The sediment and the media remnant were respectfully suspended by vortaking. The result of this suspension was wholly cultured and planted in the solid media in order to be askew Lowenstein Jensen (L.J Media) and Middlebrook 7H10. Culture method was still gold standard method since from the infection source, the M. tuberculosis bacteria, as the cause of infection according to postulate Koch, could be isolated. The advantage of this culture method that it has sensitivity more than $95 \%$ and enabled to detect M. tuberculosis 1-100 per ml. sputum, and its specification nearly $100 \%$ especially if the standard procedure is conducted appropriately. ${ }^{16,17}$

Solid media was used because it could detect the morphology of $M$. tuberculosis colonies. The solid media used in this research was a Lowenstein Jensen (conventional standard media), that included into egg base media group. This media was used to isolate $M$. tuberculosis primer. The characteristic shape of colony $M$. tuberculosis in the Lowenstein Jensen (Figure 1) was rough characteristic 


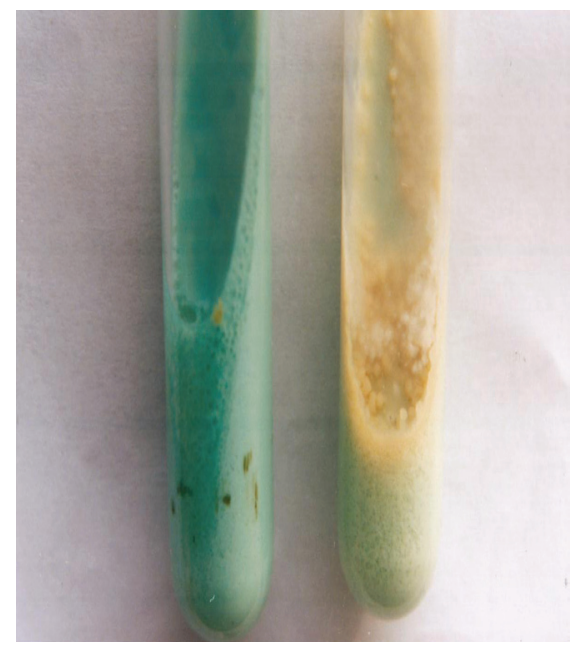

Figure 1. Culture of M. tuberculosis on the Lowenstein-Jensen media: Organism exhibiting typical rough colonies, white cream-coloured (no pigmented), broccoli likeflower-shaped (right tube).

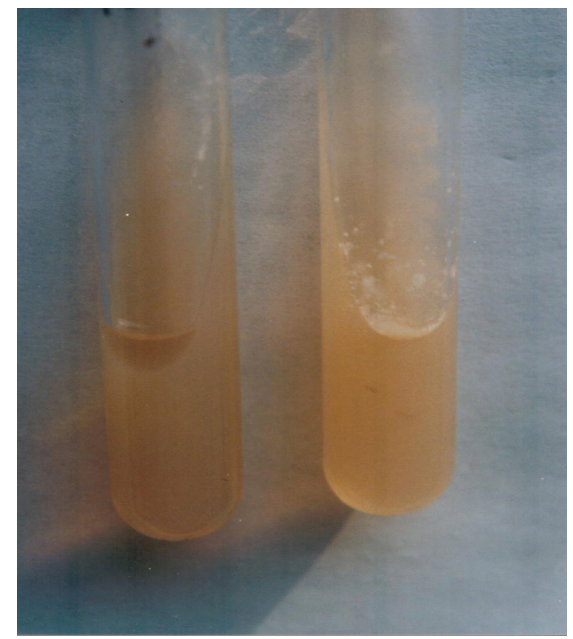

Figure 2. Culture of M. tuberculosis on the Midllebrook 7H10 media, Organism exhibiting typical rough colonies formation, dry, scaling, yellowish cream-coloured on the surface (right tube).

colonies, yellowish-coloured, non-pigmented, resembling to broccoli flower-shaped. ${ }^{13,14,15}$ Culture examination was carried out once a week and if there was no growth after 8 weeks, the culture would be stated negative. After observing the first week, there had not been any growth yet, in the third week (the $22^{\text {nd }}$ day) there was growth of characteristic colony. This result was not far different with Pfyffer's research ${ }^{17}$ where examination time for all types of mycobacterium with Lowenstein-Jensen was averagely 23,1 days, while the result of Susilo's research ${ }^{18}$ of which samples were taken from the sputum of lung tuberculosis patients, the mean of their growth were 16.48 days.

In the Middlebrook media $7 \mathrm{H} 10$, that is one of the groups of commercial agar base media, the culture result was the same with the Lowenstein Jensen media. The culture examination was conducted once a week, and if there was no growth after 8 weeks, it was stated that the culture was negative. In this research, after observing the first week (the $6^{\text {th }}$ day), the growth was present, the growth of colony was faster and more obvious because of the transparent media. The shape of characteristic colony of M. tuberculosis bacteria in this media (Figure 2) was rough colonies in dry shape, scaling, cream-colored. ${ }^{13,14,15}$ This result was not far different from Pfyffer researchr ${ }^{17}$ where the examination time toward all types of mycobacterium using Middlebrook media 7H10, the mean was 6.4 days, while the result of Susilo's research ${ }^{18}$ in which samples were taken from the sputum of lung tuberculosis patients, the growth mean was 6,41 days. Thus, the use of duplo media, Lowenstein-Jensen (L-J media) and Middlebrook $7 \mathrm{H} 10$ not only improved the detecting performance or sensitivity but also accelerated the positive growth.

In both media, the growth of bacteria was showed by the presence of characteristic colony figures (Figure 1 and 2). In observing the growth of $M$ tuberculosis bacteria, generally, the growth decreased after the fourth week, the growth was absent through the sixth week and the death was started in the eighth week. The observation toward the growth of $M$. tuberculosis bacteria from swabbing the oral lesion that was cultured according to the growth pattern of bacteria in general where the cell division of M. tuberculosis bacteria is 18-24 hours. The growth of a bacteria colony in the solid media was expressed after the age of colony had been more than a week, however, if the number of bacteria coming from the specimen planted in the media was bulk, the characteristic colony would be detected faster ${ }^{15}$ It supported the research conducted by Pfyffer ${ }^{17}$ and Susilo ${ }^{18}$ where the mean time of the growth of bacteria colony was faster compared to the result of this research due to the specimens such as the sputum of tuberculosis sufferers, while in this research the samples were taken from the swabbing applied in the oral lesion in which the bacteria number was less compared to the sputum.

Conclusion: it was inferred that Mycobacterium tuberculosis could be detected from the oral lesion by swabbing using culture method, and the growth pattern of Mycobacterium tuberculosis in general as well.

\section{REFERENCES}

1. Davis BD, Dulbecco Reirsen HN, Ginsberg HS. Growth and death of bacteria, protein synthesis \& location, mycobacteria. In Microbiology. $4^{\text {th }}$ ed. Philadelphia: JB Lippincot \& Company; 1990. p. 51-63, 105-21, 647-64.

2. Gloucester. Essentials of tuberculosis control for the practising physician. Canadian Thoracic Society Canadian Medical Association Journal 1994; 150: 561-71.

3. Martin G, Lazzarus A. Epidemiology and diagnosis of tuberculosis: Recognition at risk patient is key to prompt detection. Journal Simposium 2000 August; 108(2). 2000, Post Graduate Medicine.

4. Depkes RI. Pedoman Nasional Penanggulangan Tuberkulosis oleh Pusat Kesehatan Kerja. 2005. Available at: http:/www.depkes.go.id/ index.php?option=articles?\&task=viewarticles\&article $=154 \&$ itemd $=3$. Accessed July 5, 2005 . 
5. Jones JH, Mason DK. Oral manifestation of systemic disease. London, Philadelphia, Toronto: WB Saunders Company Ltd; 1990. p. 349-52.

6. Sonis ST, Fazio RC, Fang LF. Principal and practice of oral medicine. Philadelphia, London, Toronto, Mexico, City, Rio de Janeiro, Sydney, Tokyo: WB Saunders Company; 1995. p. 192-3, 197.

7. Lynch MA. Burket's oral medicine diagnosis and treatment. $10^{\text {th }} \mathrm{ed}$. Philadelphia, Toronto: JB Lippincott Company; 2003. p. 441-4.

8. Fujibayashi T, Takahashi Y, Yoneda T. Tuberculosis of the tongue: a case report with immunologic study. Oral Surg 1979; 47:427.

9. Hashimoto Y, Tanioka H. Primary tuberculosis of the tongue : report of case. J Oral Maxillofac Surg 1989; 47:746-7.

10. Mignogna MD, Muzio LLO, Favia G, Ruoppo E, Sammartino G, Zarelli C, Bucci C. Oral Tuberculosis : a clinical evaluation of 42 cases. Mac Millan Published Ltd, Oral Disease 6. 2000. p. 25-30.

11. Bricker SL, LangLais RP, Miller CS. Oral diagnosis, oral medicine and treatment planning. Pensyluania: Lea and Febiger; 1994. p. 180-91.

12. Crofton SJ, Horne N, Miller F. General background for clinical tuberculosis; tuberculosis in children; pulmonary tuberculosis in adult; treatment tuberculosis. In: clinical tuberculosis. London and Basingstoke: Mac Milan Press LTD; 1992. p. 1-27, 29-82, 89-115, 139-71.
13. Richard J, Wallace Jr, Barbara A, Ellison B, Hall L, Roberts G, Linda B. Clinical and laboratory feature of Mycobacterium tuberculosis. J Clin Microbiol 2002; 40:2930-5.

14. Baron EJ, Peterson LR, Finegold SM. Mycobacteria. In: Bailey, Scott's, editors. Diagnostic microbiology. St Louis, Baltimore, Boston, Chicago, London, Madrid, Philadelphia, Sydney, Toronto: Mosby Year Book, Inc; 2002. p. 550-633.

15. Boyd RF. Mycobacterial genetics, Mycobacterium tuberculosis. In: Basic medical microbiology. $5^{\text {th }}$ ed. Boston, New York, Toronto, London: Little Brown and Company; 1995. p. 61-81, 331-4.

16. De Kantor IN, Kim SJ, Frieden T. Laboratory services in tuberculosis control. Culture Part III. World Health Organization. 1998.

17. Pfyffer, Patel AM, Abrahams EW. Micobacteria growth indicator tube. J Clin Micr 1997; 35:767-70.

18. Susilo B. Studi komparasi pemeriksaan kultur M.tuberculosis dengan media Lowenstein Jensen, Middlebrook 7H10 komersial dan Middlebrook 7H10 modifikasi. Thesis. Surabaya: Fakultas Pascasarjana Universitas Airlangga; 2003. p. 60-90. 